\title{
Ramón Yzquierdo Peiró (Ed.), Maestro Mateo, Santiago de Compostela, Fundación Catedral de Santiago, 2019, 152 páginas
}

\author{
Sara Ennis \\ saraennis13@gmail.com \\ Instituto de Investigaciones en Humanidades y \\ Ciencias Sociales (UNLP - CONICET). Facultad de \\ Humanidades y Ciencias de la Educación. Universidad \\ Nacional de La Plata, Argentina
}

Cita sugerida: Ennis, S. (2021). [Revisión del libro

Maestro Mateo de R. Yzquierdo Peiró]. Olivar,

21(34), e112. https://doi.org/10.24215/18524478e112

Lo visual es clave en la edición de Maestro Mateo a cargo de Ramón Yzquierdo Peiró, que además de incorporar alrededor de cincuenta imágenes y láminas a color, incluye textos de José Carlos Valle Pérez, Manuel Antonio Castiñeiras González, Ramón Yzquierdo Perrín y el mismo Ramón Yzquierdo Peiró. El acertado balance entre ambos formatos hace de la lectura de este libro un grato recorrido por tiempo y lugar a través de la historia de la obra del Maestro Mateo en la Catedral de Santiago de Compostela, sin perder en ningún punto la atención al detalle.

La publicación de esta obra no es el único curso de acción que se ha tomado en los últimos años para revalorizar esta catedral, sino que es parte de una serie de proyectos que han permitido profundizar el conocimiento sobre la historia de la emblemática construcción y sobre el trabajo del Maestro Mateo. Uno de esos proyectos fue la restauración del Pórtico de la Gloria, que concluyó en 2018. Al tener esto en cuenta, las "reflexiones sobre el Maestro Mateo" (que es como se titula el primero de los tres capítulos que, junto 
al catálogo y apéndice, componen el libro) pueden ser vistas bajo una nueva luz: la historia de la basílica del apóstol Santiago, lejos de poder ser vista como ya concluida, sigue desenvolviéndose con cada suceso que presencia, con cada instancia de renovación y restauración. En esta primera parte, José Carlos Valle Pérez nos presenta al Maestro Mateo y nos introduce a los puntos principales de su obra. Así, este capítulo funciona como una entrada a la experiencia de lectura que continuará en los que le siguen. Deja saber al lector desde un comienzo que desconocemos los detalles de la biografía de Mateo, pero que se cuenta con dos testimonios de su paso por la catedral: el documento mediante el cual el rey Fernando II otorga una pensión vitalicia al Maestro por su obra en el sitio, y la inscripción en los dinteles sobre los que se levanta el tímpano que ocupa el tramo central del nártex occidental catedralicio, que menciona al magister. El lector no especializado se encontrará con la necesidad de reponer un determinado glosario arquitectónico, y como recompensa por su esfuerzo, podrá visualizar con precisión cada aspecto de la catedral que el texto le proponga conocer.

La historia comienza, como nos hace saber Ramón Yzquierdo Peiró en el segundo capítulo ("El Maestro Mateo en la Catedral de Santiago"), en 1075, cuando el auge de las peregrinaciones lleva a la construcción de una nueva basílica. Y es en 1168 cuando Fernando II confirma en la dirección de los trabajos para concluir las obras al Maestro Mateo. Lo que sabemos de él es, principalmente, lo que la catedral y lo que hoy vemos de su proyecto tienen para contar. Yzquierdo Peiró nos comenta que la historiografía ha hipotetizado mucho sobre Mateo, y recopila en este capítulo la información con la que contamos al día de hoy. A la vez, llama la atención sobre detalles importantes, como el hecho de que en la inscripción del Pórtico de la Gloria (1118) sólo se lo mencione a él y no a ningún rey o prelado, lo cual demuestra una consideración del artista prácticamente inédita para la época, sobre todo en España, y permite contextualizar su trabajo en torno a la década de 1160.

La ejecución del proyecto mateano se inició con el Pórtico de la Gloria y su fachada exterior, y concluyó con la consagración de la catedral en 1211. Pero el autor nos recuerda que todos los elementos que integraron la intervención mateana en Compostela deben verse como parte de un todo, y no como una serie de obras inconexas. Su proyecto también incluyó la construcción de un coro de granito, en cuyo programa iconográfico continuaba el mensaje apocalíptico y salvífico del Pórtico de la Gloria. A lo largo del siglo XVI, cambios litúrgicos, modificaciones en la reglamentación capitular y las disposiciones del Concilio de Trento hicieron que el coro perdiese parte de su funcionalidad. En los primeros días de 1604 comenzó a derribarse el coro de Mateo para sustituirlo por uno nuevo, realizado en madera. Tras la consagración de la catedral no se terminaron las obras en ella, una constante a lo largo de toda su historia. Y gracias a los talleres de influencia mateana, el estilo del Maestro seguiría presente, marcando un estilo que sería parte de la identidad de esas tierras hasta el final de la Edad Media.

Manuel Antonio Castiñeiras González desarrolla en el tercer capítulo la historia del Pórtico de la Gloria como puerta del Cielo. Como ya mencionamos, las peregrinaciones cumplieron un rol clave en la construcción de la basílica que, ubicada en un extremo de Occidente, se consideró metafóricamente entrada en el Paraíso. El inicial programa iconográfico, que guio la construcción de la catedral románica entre 1075 y 1211, tuvo en cuenta el valor de esas metáforas, y el edificio se elevó siguiendo una particular topografía sagrada. Y cuando a fines del siglo XII entró en escena el Maestro Mateo, aumentó y amplificó esas referencias simbólicas, poniendo al día el monumento buscando satisfacer la experiencia visual de la peregrinación. Eso explica el agregado de la estatua de Santiago el Mayor: el peregrino encontraría en ella la "presencia corpórea" del santo que anhelaba, relacionada con la creciente devoción bajomedieval de experimentar visualmente lo sagrado. Castiñeiras González explica cómo esto provocó una revolución en la iconografía jacobea, así como en la percepción de Santiago por parte de sus peregrinos. Factores como el lugar del coro en la basílica y la forma en la que entraba la luz también habrían jugado su parte en amplificar el sentido visionario del programa apocalíptico de la obra de Mateo.

Aunque desconocemos el aspecto de la fachada exterior mateana (realizada entre 1188 y 1211), sabemos que era, junto con la decoración interior del nártex, la cripta y la galería de la tribuna, parte del conjunto de la obra del Maestro Mateo. Castiñeiras González reúne con sus palabras fragmentos de esa obra, que recoge de 
distintos tiempos y espacios, recurriendo al diálogo entre texto e imagen característico de esta edición para recrear ante el lector la visio del conjunto compostelano que habría impactado al peregrino de entonces, y aún mueve al visitante de hoy.

La primera lámina doble que encontramos al abrir el libro es una reproducción fotográfica del Pórtico de la Gloria, tomada desde un ángulo central inferior: lo vemos como lo veríamos si estuviéramos allí mismo, en la catedral. Esta primera experiencia visual marca la pauta de la intención que parece atravesar todo el libro: intención de integrar al lector, hacerle partícipe del recorrido por el sitio y la historia del proyecto del Maestro Mateo. Quizás el viajero que, en su paso por Santiago, visite la catedral, se lleve consigo este libro como recuerdo del recorrido que hizo en persona, como registro fotográfico impreso de lo que maravilló a sus propios ojos. En ese caso, se encontrará también con el valor de las palabras que dialogan con dichas imágenes, que enriquecerán a posteriori su vivencia allí.

Pero en relación con esto, vale tener en cuenta el hecho de que este libro fue impreso en el año 2019. Después de un largo proceso, en el verano del 2018 volvió a posibilitarse el acceso del público al Pórtico de la Gloria, tras su restauración. Como mencionamos, la publicación de esta obra es parte de una serie de proyectos vinculados con la puesta en valor de la catedral. Pero las nuevas circunstancias que llegaron con el 2020 implicaron la necesidad de replantear todo proyecto. Todo debió reformularse, empezando por cómo acercar la catedral al público cuando el público ya no podía acercase a la catedral. Fue entonces cuando este libro, aunque publicado antes de la crisis sanitaria que comenzó poco después de su debut en los estantes, atravesó también su propia revalorización: cuando los viajes parecían imposibles, y las visitas al recientemente restaurado Pórtico de la Gloria habían debido una vez más ser suspendidas sin ninguna seguridad sobre cuándo podrían ser reestablecidas, el formato de este libro, colmado de color e información sin dejar de ser ameno, invitó a otro tipo de viaje, uno que el lector podía hacer desde cualquier parte del mundo. Todo esto no quiere decir que haya decrecido su valor ahora que las visitas presenciales han sido reestablecidas: sigue siendo el acompañante ideal para quien recorra la basílica y anhele conocer más de su historia, y sigue ofreciendo una valiosa experiencia para quien quiera hacer eso mismo sin haberla visitado en persona. Pero sí hemos de destacar su lugar, en la historia de este libro y su lectura, como remanso en las tormentosas circunstancias a la que nos enfrentamos globalmente durante la pandemia, atributo seguramente inesperado por sus editores, pero bienvenido por todo lector. 